ФІНАНСОВЕ ПРАВО

КІКАЛІШВІЛІ М. В., кандидат юридичних наук, доцент, доцент кафедри кримінального правата кримінології (Київський національний університетімені Тараса Шевченка)

УДК 343.2

DOI https://doi.org/10.32842/2078-3736-2019-6-2-14

\title{
ВИЗНАЧЕННЯ ПОНЯТТЯ СТРАТЕГІЇ Й ТАКТИКИ ПРОТИДІЇ КОРУПЦЙНІЙ ЗЛОЧИННОСТІ ЯК ЕЛЕМЕНТІВ АНТИКОРУПЦЙНОӤ ПОЛІТИКИ ТА ЇХ СПІВВІДНОШЕННЯ
}

Стаття присвячена розгляду питання та проблемних аспектів розвитку та вдосконалення елементів антикорупційної політики - стратегії й тактики протидії корупційній злочинності.

Автор зазначає, що розуміння антикорупційної політики з її елементами стратегією та тактикою в рамках протидії корупції набуває дедалі більшої актуальності для нашої держави.

У статті розкриваються визначення понять «антикорупційна політика», «стратегія» й «тактика», більш ретельно досліджуються категорії «стратегія протидії корупційній злочинності» та «тактика протидії корупційній злочинності», а також наводяться тактичні прийоми при розслідуванні корупційних злочинів, а також їх поняття.

Під терміном антикорупційна політика автор розуміє головний вектор політики протидії корупційній злочинності, що перевтілюється в стратегію й тактику реалізації політики протидії корупції. Стратегія відповідає на питання що робити, а тактика - як робити.

Автором звертається увага на те, що за відсутності стратегічних концептуальних ідей й мети, принципів й пріоритетів, довгострокових програм загальнодержавного типу, що засновуються на науковому підгрунті, не може бути жодної антикорупційної політики, а виключно її видимість. В стратегічних напрямках антикорупційної політики формується антикорупційна тактика, котрою передбачено розробку визначених задач та способів їхнього вирішення.

У статті також досліджується поняття тактичних прийомів при розслідуванні корупційних злочинів, а також їх перелік та роль. Тактичними прийомами в цій ситуації $€$ комплекс слідчих (розшукових) дій гласного та негласного типу й інших заходів, котрий направлено на доказування фактів й обставин, що відіграють важливу роль задля розслідування злочинів із корупційною складовою частиною.

Автор у межах статті розглядає тактичні прийоми таких дій, як: проведення огляду місця події; затримання особи, що підозрюється у здійсненні корупційного злочину; проведення обшуків місця проживання (роботи) підозрюваної особи, інших місць (дачі, гаражів), а інколи і місць проживання близьких і рідних осіб підозрюваних;допит й перехресний допит; судові експертизи; а також слідчий експеримент, пред’явлення особи або речей задля впізнання й інші слідчі дії.

Ключові слова: корупиія, корупиійна злочинність, стратегія, тактика, антикорупційна політика.

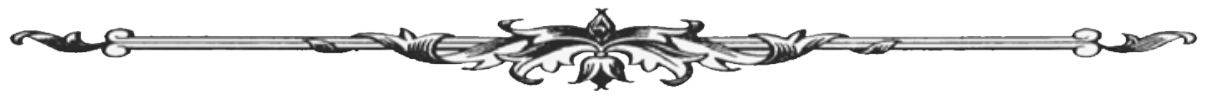


The article is devoted to consideration problem aspects of perfection of anticorruption policy's elements - strategy and tactics of counteraction to corruption criminality.

The author notes that the understanding of anti-corruption policy with its elements (strategy and tactics) in the fight against corruption is becoming increasingly important for our country.

The article reveals definitions of the concepts of "anti-corruption policy", "strategy" and "tactics", more thoroughly researches the categories of "strategy of counteraction to corruption criminality" and "tactics of counteraction to corruption criminality", and also gives tactical methods in the investigation of corruption crimes and the definition of this concept.

The concept of anti-corruption policy is the main vector of policyof counteraction to corruption criminality, which is transformed into the strategy and tactics of anticorruption policy implementation. The strategy answers the question of what to do, and the tactics - how to do it.

The author draws attention to the fact that in the absence of strategic conceptual ideas and goals, priorities, long-term national programs, which are based on scientific basis, there can be no anti-corruption policy. In the strategic directions of anti-corruption policy, anti-corruption tactics are formed, which provides for the development of certain tasks and ways of solving them.

The article also explores the concept of tactics in the investigation of corruption crimes, as well as their list and role. Tactical methods in this situation are a set of investigative actions and other measures aimed at proving the facts and circumstances that play an important role in the investigation of corruption crimes.

The author considers such tactics as: conducting an inspection of the scene of an incident; detaining a person suspected of committing a corruption offence; conducting searches of the suspect's place of residence (place of work), other places (summer residences, garages) and, in some cases, the residence of the suspect's family members and relatives; questioning and cross-examination; forensic examinations; and conducting investigative experiments, presenting a person or thing for identification and other investigative actions.

Key words: corruption, corruption criminality, strategy, tactics, anti-corruption policy.

Постійна боротьба із корупційною злочинністю та загалом корупцією в Україні все ще залишається в центрі уваги суспільства, оскільки сучасні масштаби та системний характер цього явища $є$ значною загрозою не лише економічній стабільності нашої держави, однак і національній безпеці.

На жаль, стан корумпованості (особливо серед вищих посадовців) в нашій державі постійно зростає. Зазначена негативна тенденція спостерігається, не дивлячись на позитивні зрушення, які стали відбуватися починаючи 32014 р. (створення ряду антикорупційних органів із спеціальними повноваженнями, вдосконалення нормативно-правової бази антикорупційного характеру, загальне формування негативного відношення до корупції серед населення шляхом залучення до подібної роботи громадських об'єднань і ЗМІ).

Виходячи із зазначеного вище, очевидним стає, що питання розуміння антикорупційної політики 3 його елементами - стратегією та тактикою в рамках протидії корупції набуває все більшої актуальності для нашої держави. Аби дієво протидіяти явищу корупції, необхідно повністю вивчити зазначений феномен. Щоб мати повноцінне уявлення про таке явище, як корупційна злочинність, не останнє місце займає задача визначення поняття стратегії й тактики протидії корупційній злочинності як елементів антикорупційної політики та їх співвідношення.

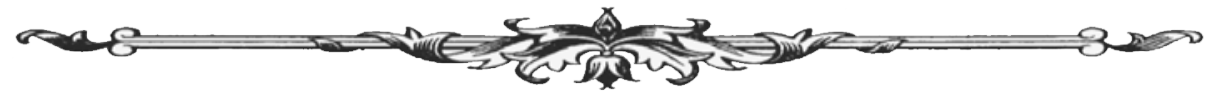


Проблемним питанням протидії корупції присвячено численні монографії, публікації, певні аспекти було обговорено на науково-практичних конференціях. Базові наукові дослідження в межах даного напряму здійснюються вітчизняними вченими: В.Б. Авер'яновим, О.М. Бандуркою, А.В. Волошиною, І.П. Голосніченком, Н.О. Гуторовою, Р.А. Калюжним, С.В. Ківаловим, Н.Р. Нижник, В.В. Цвєтковим, В.О. Шамраєм, Ю.С. Шемшученком, В.К. Шкарупою.

Зважаючи на об'ємно сформульовану фундаментальну базу наукових робіт, слід зауважити, що аспекти визначення поняття стратегії й тактики протидії корупційній злочинності як елементів антикорупційної політики вимагають подальших досліджень, що і було поставлено за мету цієї статті. Задля досягнення зазначеної мети, висунуто наступне завдання: дослідження визначень поняття «антикорупційна політика», іiі складових «стратегія» та «тактика», більш детальне ознайомлення 3 категоріями «стратегія протидії корупційній злочинності» та «тактика протидії корупційній злочинності», а також дослідження тактичних прийомів при розслідуванні корупційних злочинів.

Переходячи до безпосереднього розгляду обраної теми, слід відмітити, що певні автори зауважують, що кримінологічна політика постає науково обгрунтованою стратегією й тактикою запобігання злочинності завдяки системі заходів спеціально-кримінального характеру, а також завдяки відверненню певних злочинів та покладання їм краю. Виходячи із поняття кримінологічної політики, стає зрозумілим, що державною антикорупційною політикою постає науково обгрунтовані стратегія й тактика держави щодо запобігання корупційній злочинності.

Антикорупційною політикою постає головний вектор політики протидії корупційній злочинності, що перевтілюється в стратегію й тактику реалізації політики протидії корупції. Стратегія й тактика відповідають на наступні два одвічні запитання: що робити і як робити. На перше запитання відповідає стратегія, а на друге - тактика [12, с. 186].

Задля більш детального розуміння стратегії й тактики протидії корупційній злочинності, нижче пропонується проаналізувати поняття стратегії й тактики протидії корупційній злочинності.

Певні кримінологи вважають, що стратегією постають засоби досягнення мети, мистецтво боротьби зі злочинністю загалом або окремими їі різновидами, вибір вирішального напряму задля досягнення раніше накресленої мети [7, с. 327].

Тактикою постає елемент стратегіі, ті визначені поточні задачі, котрі вирішують в рамках стратегій аби досягти їі кінцеві цілі [3, с. 243]. Стосовно діяльності із запобігання злочинності, під тактикою розуміється найбільш спрямована до досягнення цілей система прийомів, методів, способів правомірного, науково обгрунтованого характеру, а також винахідок під час виконання заходів аби реалізувати стратегії, що зазначаються в рамках Державної програми стратегій запобігання злочинності [4].

Зупиняючись і детальніше аналізуючи питання стратегії протидії корупційній злочинності, зауважимо, що як вважає О.М. Литвинов, кримінологічною стратегією можна визнати систему обгрунтованих і прийнятих в офіційному порядку поглядів, принципів та норм щодо шляхів, засобів та механізмів із захисту життєво істотних громадських, суспільних, державних, правових інтересів від загроз злочинності внутрішнього та зовнішнього характеру [9, с. 138].

Стратегія - це визначення перспективних цілей і пріоритетів діяльності, чільних напрямів і засобів реалізації зазначених цілей на основі державницької, національної ідеології правової соціальної держави [12, с. 187].

Здійснюючи аналізування однієї 3 найбільш пріоритетних стратегій запобігання та протидії злочинності, С.С. Шрамко [13, с. 195] зазначив, що, зважаючи на поняття та специфіку стратегії зменшення вчинення злочинів і правопорушень, ця стратегія вперше була розроблена в якості соціального методу містобудування, архітектурного та дизайнерського убезпечення підприємств промислового типу, освітлення, житлових приміщень, бізнесу, банків, магазинів, застосування систем із контролювання, формування ефективніших фізич-

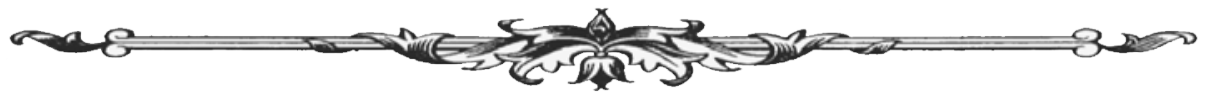


них перепон, бар'єрів для проявів злочинного типу, здійснення поліцейського патрулювання разом із громадянами, тощо. У сучасному вигляді ця стратегія може бути представлена в якості стратегії «захисного простору і фізичних бар'єрів для злочинності» [5, с. 64-65].

Таким чином, зважаючи на всі вищенаведені тлумачення, можна визначити те, що стратегією постає обгрунтована потребою система заходів, що спрямовано на отримання визначених цілей.

Цілком зрозуміло, що протидія корупції залежить від загальнонаціональної стратегії держави по викоріненню цього явища.

На сьогоднішній день триває робота над одним з основних документів законодавчого характеру, котрим буде визначатися антикорупційна політикаУкраїни в найближчій перспективі - проектом стратегії протидії корупції. Беручи до уваги те, що проект Антикорупційної стратегії на 2018-2020 pp. [10, с. 10], котрий розроблювався Національним агентством з питань запобігання корупції, хоч і було ухвалено урядом України, експерти доволі критично поставилось до змісту цього документу, адже певні із заходів Антикорупційної стратегії було сформульовано таким чином, що здається, що розробники проекту писали законопроект не для мети корупційного запобігання, а із турботою про корупціонерів й до них наближених. Таким чином, з 2018 р. в нашій державі нема Антикорупційної стратегії комплексного документу загальнодержавного рівня, котрим визначаються заходи із запобігання та протидії корупції.

Антикорупційна стратегія постає істотною структурною складовою антикорупційної політики. За відсутності стратегічних концептуальних ідей й мети, принципів й пріоритетів, довгострокових програм загальнодержавного типу, що засновуються на науковому підгрунті, не може бути жодної антикорупційної політики, а виключно їі видимість. В стратегічних напрямках антикорупційної політики формується антикорупційна тактика, котрою передбачено розробку визначених задач та способів їхнього вирішення. Системне поєднання проаналізованих стратегічних напрямків корупційної протидії можна визнати як запоруку дієвості антикорупційної політики, вони вимагають подальшого наукового поглибленого аналізу [8, с. 180].

Природно, що подібна Стратегія потрібна державі й стратегічні плани по боротьбі 3 корупцією повинні оновлюватися, оскільки сама корупція зазнає постійних динамічних змін, проте, багато в чому зазначена Стратегія дублює ті, що вже стали історією. Відтак зазначена Стратегія та подібні їй нормативні документи не дають реальних шляхів протидії корупції в державі.

Стратегія протидії корупційній злочинності $є$ системою узгодженої, безперервної й постійно діючої на рівніміжнародного, державного, міжрегіонального, регіонального типу організації заходів стосовно усунення корупційних проявів, причин іiі існування й умов поширення. Базаданої різнопланової діяльності формується із системи взаємопов'язаних, взаємодоповнюючих й упорядкованих заходів протидії (подолання, нейтралізації, стримування) корупційної злочинності.

Нижче пропонується зупинитися на тактиці протидії корупційній злочинності, що постає оптимальним сполученням індивідуальних форм впливу, оперативно-розшукових заходів гласного й негласного типу, методів та засобів переконання й примусу аби здійснити профілактику й припинити корупцію.

Велика кількість науковців зауважують, що криміналістичною тактикою обіймається центральна позиція в криміналістиці, тактикою є загальна система розслідування злочинів $[2$, c. 28]. Ця роль їй відведена через те, що криміналістичну техніку застосовують за допомогою тактики, без неї вона є безпредметною. Методикою розслідування певних різновидів злочинів здійснюється розробка прийомів тактичного характеру із розслідування певних різновидів злочинів, іншими словами знову відбувається грунтування на тактиці [11].

Нижче пропонується дослідити тактичні прийоми під час розслідування корупційних злочинів. Так, тактичними прийомами в цій ситуації є комплекс слідчих (розшукових) дій гласного та негласного типу й інших заходів, котрий направлено на доказування фактів

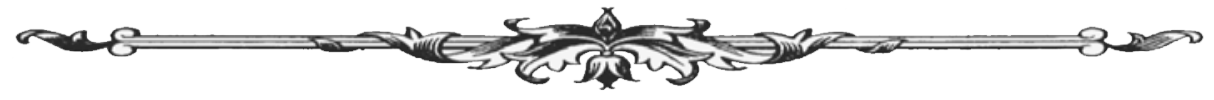


й обставин, що відіграють важливу роль задля розслідування злочинів із корупційною складовою [6, с. 142-143].

Співробітництво слідчого й оперативних працівників після одержання інформації щодо вчинення кримінального корупційного правопорушення відіграє істотну тактичну роль. Зважаючи на тактичні характерні риси розслідування злочинів з корупційною складовою частиною, слідчий має здійснити аналіз та прийняти рішення виключно беручи до уваги надані йому матеріали або досліджені особисто обставини. Це правило пояснюється тим, що слідчий може бути введений в оману оперативними працівниками стосовно окремих обставин здійснення злочину, зокрема, завдяки неофіційному повідомленню оперативної інформації, що надалі буде легалізованой визнано доказом [6, с. 143].

Важливу роль під час досудового розслідування відіграє ефективне слідче проведення огляду місця події, а також затримання особи, що підозрюється у здійсненні корупційного злочину. Здійснюючи аналізування слідчих ситуацій, котрі реалізуються при розслідуванні корупційних злочинів, виділяють три основні місця проведення огляду, зокрема: службове приміщення, де працює злочинний суб'єкт (наприклад, робочий кабінет, тощо); житло або інше володіння особи; інші місця, огляд котрих може знадобитися: місце зустрічі корупціонерів не у службових приміщеннях (наприклад, кафе, інші громадські місця тощо), автомобілях, житлових приміщеннях тощо [6, с. 143].

Складність затримання підозрюваного у здійсненні злочину зумовлюється зазвичай характерними рисами суб'єкта злочину, пов'язаного із корупцією. Слідчий, прокурор мають бути готові до імовірних спроб впливання на них заради (не) прийняття відповідних рішень процесуального характеру, зокрема і стосовно процедури затримання. Такий вплив може бути виражено впобажаннях (не) вчинити певнідії за матеріальну вигоду, через погрози настання наслідків негативного характеру у випадку реалізації слідчих дій, тощо.

Починаючи досудове розслідування також здійснюють проведення обшуків місця проживання (роботи) підозрюваної особи, інших місць (дачі, гаражів), а інколи і місцепроживання близьких й рідних осіб підозрюваних, у відповідності до приписів ухвали слідчого-судді. За потреби проведення обшукув декількох місцях (групові обшуки), ці слідчі дії бажано здійснювати одночасно, а отже варто сформувати декілька угрупувань оперативних працівників, що будуть скеровуватися слідчим чи прокурором.

Тактичні прийоми допиту (як обов'язкової слідчої дії) підозрюваних у справах щодо злочинів, пов'язаних із корупцією, дуже відрізняються від тактики допиту, що застосовується під час розслідуваннярешти злочинів. У складних проблемно-конфліктних випадках, що заявляються при розслідувані злочинів корупційної спрямованості, до головних прийомів допиту підозрюваних осіб прийнято відносити пред’явлення доказів, перш за все, різноманітних документів, знайдення та пред'явлення допитуваній особі логічних суперечностей в іїсвідченнях, зупинення брехні, нейтралізацію мотивів протидії. Обрання та здійснення прийомів допиту підозрюваного обумовлюється змістом реального слідчого випадку, характерними рисами особистості допитуваного [1].

За наявності протиріч між показаннями допитаних осібпри розслідуваннізлочинів корупційної природи варто одночасно допитатидекількох й більше раніше допитаних осіб аби з'ясувати причини розбіжностей в їх показаннях.

Надалі при розслідуванні злочинів, пов’язаних із корупцією, можуть бути призначені різноманітні види судових експертиз, а саме експертизи:

- судово-економічного характеру - аби перевіряти фінансові та господарські операції підприсмств, організацій чи окремих посадовців; задля перевірки планування промислової, товарної, фінансової природи;

- судово-товарознавчого типу - аби встановити якість готових промислових та продовольчих товарів, їх сортність, вартість, тощо;

- судово-технічного спрямування - аби з'ясувати причини порушень процесів технологічного характеру, термінів будівництва тощо;

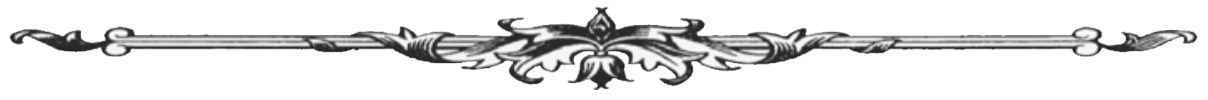


- криміналістичної (техніко-криміналістичної) природи - аналізування документів;

- почеркознавчого, фоноскопічного й інших типів особливих експертиз [6, с. 146].

За потреби при розслідуванні злочинів, що пов’язано із корупцією,здійснюється проведення слідчого експерименту, пред’явлення особи або речей задля впізнання й інші слідчі діï.

Реалізація тактичних прийомів під час слідства у справах щодо корупційних злочинівнадасть можливість завершити досудове розслідування та скласти обвинувальний актйгарантує належну процедуру розгляду справи в суді.

Отже, підсумовуючи усе вищевикладене можна дійти висновку, що антикорупційною політикою постає головний вектор політики протидії корупційній злочинності, що перевтілюється у стратегію і тактику реалізації політики протидії корупції. Антикорупційною стратегією є той компас, що дозволяє віднайти єдино правильний шлях до науково обгрунтованих, раціональних рішень у межах сфери протидії корупційній злочинності, а тактика протидії корупційній злочинності допомагає реалізувати такі рішення та саму стратегію.

Стосовно співвідношення двох елементів антикорупційної політики, можна сказати, що стратегія і тактика дають відповіді на два одвічні питання: що робити і як робити. На перше питання дає відповідь стратегія, на друге - тактика.

Підводячи підсумок, варто зазначити, що формування стратегії й тактикив межах сфери протидії корупційній злочинності мають вагоме значення задля втілення в життя як антикорупційної, так і державної політики протидії злочинності загалом, оскільки в ній знаходить вираження політична воля суспільства, у формі політико-правових ідей втілюються основні засади організації та провадження відповідної діяльності, визначаються пріоритети iii гуманітарної, економічної та правозастосовної основи, створюються передумови для формування адекватних механізмів реалізації правоохоронного потенціалу та запровадження новітніх підходів із метою оптимізації та підвищення ефективності функціонування системи як на загальнодержавному, так і на регіональному рівнях.

\section{Список використаних джерел:}

1. Башмаков И.С. Особенности первоначального этапа расследования коррупционных преступлений, совершаемых представителями органов местной власти : автореф. ... дис. канд. юрид. наук : 12.00.09. URL: https://www.dissercat.com/content/osobennostipervonachalnogo-etapa-rassledovaniya-korruptsionnykh-prestuplenii-sovershaemykh-.

2. Гладкова Є.О. Кримінологічні засади стратегії й тактики протидії наркозлочинності в Україні : автореф. дис. ... докт. юрид. наук : 12.00.08. Харків, 2019. 41 с. URL: http://univd.edu.ua/science-issue/issue/3762.

3. Голіна В.В., Лукашевич С.Ю., Колодяжний М.Г. Державне програмування і регіональне планування заходів запобігання злочинності в Україні / за заг. ред. В.В. Голіни. Харків : Право, 2012. 304 с. URL: https://ivpz.kh.ua/wp-content/uploads/2019/02/golina_kolodzgnii_ monografiya_2012_.pdf.

4. Голіна В.В. Кримінологічні та кримінально-правові проблеми боротьби з бандитизмом: соціально-правове і кримінологічне дослідження: монографія. Харків : Регіон-інформ, 2004. С. 151-196.

5. Громадськість у запобіганні і протидії злочинності: вітчизняний та міжнародний досвід: монографія / В.В. Голіна, М.Г. Колодяжний, С.С. Шрамко та ін. ; за заг. ред. В.В. Голіни, М.Г. Колодяжного. Харків : Право, 2017. 284 с.

6. Кимлик Н.В. Тактичні прийоми розслідування злочинних корупційних діянь за новим КПК України. Європейські перспективи. 2012. № 4 (1). С. 142-146. URL: http://nbuv.gov.ua/UJRN/evpe_2012_4\%281\%29_26

7. Криминология : учебник / под общ. ред. А.И. Долговой. Москва : ИнфраM-HOPMA, 1997. 784 c.

8. Кушнарьов I.В. Стратегія протидії корупції як складова антикорупційної політики. Право і Безпека. 2012. № 5. C. 177-181. URL: http://nbuv.gov.ua/UJRN/Pib_2012_5_40.

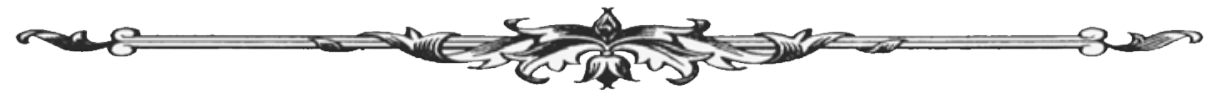


9. Литвинов О.М. Кримінологічна стратегія як компонент стратегії національної безпеки України. Право і Безпека. 2010. № 3. С. 137-141. URL: http://nbuv.gov.ua/UJRN/ Pib_2010_3_31.

10.-Миськевич Т. Стратегія антикорупційної політики України. Громадська думка про правотворення (Інформаційно-аналітичний бюлетень на базі оперативних матеріалів). № 10 (154). 2018. C. 10-14. URL: http://nbuviap.gov.ua/images/dumka/2018/10.pdf.

11. Тактика розслідування злочинів. Поняття криміналістичної тактики, іï значення в діяльності приватних детективів та детективних агентств. URL: http://www.detektiff.com. ua/rozsliduvannya-zlochiniv/.

12. Туєв О. Кримінологічна політика і стратегії протидії рейдерству. Публічне право. 2012. № 4. C. 185-190. URL: http://www.yourfuture.org.ua/ua/pb/2012/8/Tuev.pdf.

13.Шрамко С.С. Поняття та специфіка стратегії зменшення можливостей вчинення злочинів. Вісник Асоціації кримінального права України. 2017. № 1 (8). С. 193-202. URL: http://nauka.nlu.edu.ua/wp-content/uploads/2017/07/11_Shramko.pdf.

РОМАНЮК Ю. П., студент V курсу

(Навчально-науковий інститут права Університету державної фіскальної служби України)

DOI https://doi.org/10.32842/2078-3736-2019-6-2-15

\section{ПРАВОВЕ РЕГУЛЮВАННЯ ПУБЛІЧНОГО КРЕДИТУ}

У статті розглянуто сутність правового регулювання публічного кредиту, встановлені основні принципи, ідеї та чинники, які зумовлюють необхідність отримання публічного кредиту, а також визначено основні засади кредитування в Україні. Встановлено низку чинних нормативно-правових актів, які безпосередньо окреслюють тлумачення публічного кредиту та за допомогою встановлених норм регулюють публічний кредит.

Висвітлюються питання законодавчої бази, яка регулює саме в даний час відносини публічного кредиту та визначається ефективність чинної нормативно-правової бази щодо регулювання питання публічного кредиту в Україні. Наводиться низка визначень публічного кредиту та кредиту зокрема. Досліджуються методи, які виступають засобом пізнання публічного кредиту. Розглянуто питання щодо зобов'язання, позики та державного боргу.

У статті також висвітлюються теоретичні аспекти публічного кредиту, наводиться низка заходів та методів, які застосовуються в умовах сьогодення для надання публічного кредиту, звертається увага на несприятливу ситуацію в законодавчому врегулюванні питань із надання кредиту.

Чітко зазначається, що законодавство України натепер не може регулювати питання публічного кредиту, адже нема чіткого та єдиного нормативно-правового акта, який висвітлював би дане питання повністю, а не через відсилочні норми до іншого нормативного акта.

Зазначається, що правове регулювання публічного кредиту дуже важливе як для держави, так і для фізичних та юридичних осіб. Висвітлюється

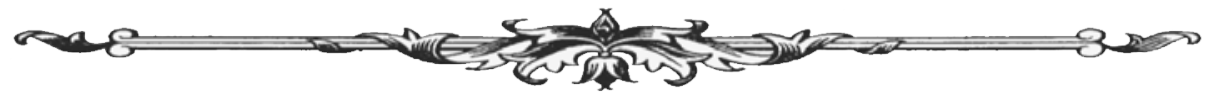

